\title{
Measurement of whole blood thrombus formation using parallel-plate flow chambers - a practical guide
}

Citation for published version (APA):

Van Kruchten, R., Cosemans, J. M. E. M., \& Heemskerk, J. W. M. (2012). Measurement of whole blood thrombus formation using parallel-plate flow chambers - a practical guide. Platelets, 23(3), 229-242. https://doi.org/10.3109/09537104.2011.630848

Document status and date:

Published: 01/01/2012

DOI:

10.3109/09537104.2011.630848

Document Version:

Publisher's PDF, also known as Version of record

Document license:

Taverne

Please check the document version of this publication:

- A submitted manuscript is the version of the article upon submission and before peer-review. There can be important differences between the submitted version and the official published version of record.

People interested in the research are advised to contact the author for the final version of the publication, or visit the DOI to the publisher's website.

- The final author version and the galley proof are versions of the publication after peer review.

- The final published version features the final layout of the paper including the volume, issue and page numbers.

Link to publication

\footnotetext{
General rights rights.

- You may freely distribute the URL identifying the publication in the public portal. please follow below link for the End User Agreement:

www.umlib.nl/taverne-license

Take down policy

If you believe that this document breaches copyright please contact us at:

repository@maastrichtuniversity.nl

providing details and we will investigate your claim.
}

Copyright and moral rights for the publications made accessible in the public portal are retained by the authors and/or other copyright owners and it is a condition of accessing publications that users recognise and abide by the legal requirements associated with these

- Users may download and print one copy of any publication from the public portal for the purpose of private study or research.

- You may not further distribute the material or use it for any profit-making activity or commercial gain

If the publication is distributed under the terms of Article $25 \mathrm{fa}$ of the Dutch Copyright Act, indicated by the "Taverne" license above, 


\section{Platelets}

\section{Measurement of whole blood thrombus formation using parallel-plate flow chambers - a practical guide}

\section{Roger Van Kruchten, Judith M. E. M. Cosemans \& Johan W. M. Heemskerk}

To cite this article: Roger Van Kruchten, Judith M. E. M. Cosemans \& Johan W. M. Heemskerk (2012) Measurement of whole blood thrombus formation using parallel-plate flow chambers - a practical guide, Platelets, 23:3, 229-242, DOI: 10.3109/09537104.2011.630848

To link to this article: https://doi.org/10.3109/09537104.2011.630848

\section{Published online: 13 Apr 2012.}

Submit your article to this journal 둔

山ll Article views: 1145

a)

View related articles $\sqsubset$

Citing articles: 36 View citing articles 


\title{
Measurement of whole blood thrombus formation using parallel-plate flow chambers - a practical guide
}

\author{
ROGER VAN KRUCHTEN, JUDITH M. E. M. COSEMANS, \& \\ JOHAN W. M. HEEMSKERK \\ Department of Biochemistry, Cardiovascular Research Institute Maastricht (CARIM), Maastricht University, \\ Maastricht, The Netherlands
}

\begin{abstract}
Custom-made and commercial parallel-plate flow chambers are widely used for studies of platelet activation and thrombus formation in whole blood at defined shear rates. When used in a reproducible way, such flow chamber devices give valuable information on the thrombogenic potential of human, mouse, or rat blood. This article aims to provide a practical guide for the use of parallel-plate flow chambers in combination with routine microscopic imaging techniques. The following methodological aspects are addressed: preparation of surface coatings, calculation of blood flow and shear rate, control of pre-analytical variables, protocols for routine performing of flow chamber tests with non-coagulating or coagulating blood, and procedures for real-time and end-point analysis of thrombus formation. Frequently encountered experimental problems and artifacts are discussed, as well as possibilities for using flow chamber devices as a diagnostic tool to test antithrombotic medication.
\end{abstract}

Keywords: Flow chamber, thrombus formation, flow dynamics, shear stress, coagulation

\section{Introduction}

The formation of a platelet thrombus at sites of vascular damage is critical to normal hemostasis. In arteries at risk, however, uncontrolled formation of a thrombus can result in vessel occlusion and provoke ischemia in heart or brain. Understanding and measurement of the process of thrombus formation is thus of key importance for research into hemostasis and thrombosis. Studies so far have distinguished three phases in thrombus formation under flow: initiation by adhesion of platelets to extracellular matrix components (e.g., platelet-collagen interaction); extension through autocrine signaling (e.g., via adenosine diphosphate (ADP) and thromboxane) and platelet co-aggregation (via the fibrinogen receptor, integrin $\alpha_{\mathrm{IIb}} \beta_{3}$ ); and perpetuation by thrombus contraction (via thrombin) and formation of a fibrin network [1-3].

Especially, in the past decade, custom-made and commercial flow devices are widely used to study the process of thrombus formation in vitro [4, 5].
The most versatile devices consist of a small parallel-plate flow chamber with technology to perfuse whole blood through the chamber at welldefined shear conditions. These flow chambers allow measurements of platelet adhesion, platelet aggregation, and coagulation within one experiment, and hence are attractive as capacity test for determining the thrombogenic activity of human or animal blood [6-9]. Flow studies using these chambers have also been quite valuable in identifying the roles of numerous platelet receptors and signaling proteins in thrombus formation. The possibilities and limitations of the most common flow chamber devices for standardized assaying of whole-blood thrombus formation have been listed in a recent paper of the Scientific and Standardization Committee (SSC) of the International Society on Thrombosis and Haemostasis (ISTH) [10].

The present methods article aims to provide a practical guide for the reproducible use of parallelplate flow chambers in combination with microscopic imaging techniques. In separate text boxes, we 
Table I. Surface coatings for the measurement of thrombus formation with parallel-plate flow chambers at indicated shear rates. Indicated materials can be used with custom-made or commercial flow devices.

\begin{tabular}{|c|c|c|c|c|c|}
\hline Coating material & $\begin{array}{c}\text { Concentration } \\
\text { applied } \\
(\mu \mathrm{g} / \mathrm{mL})\end{array}$ & Platelet receptors & Shear rate $\left(\mathrm{s}^{-1}\right)$ & $\begin{array}{l}\text { Flow time } \\
\text { (min) }\end{array}$ & Refs. \\
\hline Collagen type $\mathrm{I}^{\mathrm{a}}$ & $50-200$ & GPIb, $\alpha_{\mathrm{IIb}} \beta_{3}$, GPVI, $\alpha_{2} \beta_{1}$ & $300-1700$ & $4-5$ & {$[9,11-15]$} \\
\hline Collagen type $\mathrm{III}^{\mathrm{a}}$ & $50-200$ & GPIb, $\alpha_{\mathrm{IIb}} \beta_{3}$, GPVI, $\alpha_{2} \beta_{1}$ & $300-1700$ & $4-5$ & {$[8,16-18]$} \\
\hline${\text { GFOGER-(GPO) }{ }_{n} \text { and vWF-BP }}^{\mathrm{b}}$ & $100-1000$ & GPIb, $\alpha_{\mathrm{IIb}} \beta_{3}$, GPVI, $\alpha_{2} \beta_{1}$ & $150-3000$ & $4-10$ & {$[19-21]$} \\
\hline vWF, anti-vWF mAb & $100-1000$ & GPIb, $\alpha_{\mathrm{IIb}} \beta_{3}$ & $300-3000$ & $4-5$ & {$[2,16,22-24]$} \\
\hline Fibronectin & 300 & $\alpha_{5} \beta_{1}$ & $150-800$ & $4-10$ & {$[16,25]$} \\
\hline Fibrinogen & $100-1000$ & $\alpha_{\mathrm{IIb}} \beta_{3}$ & $150-800$ & $4-5$ & {$[16,22,26-28]$} \\
\hline Fibrin & 1000 & GPIb & $150-1700$ & $4-10$ & {$[22,28-30]$} \\
\hline Laminin & 100 & $\alpha_{6} \beta_{1}$ & $300-800$ & $4-5$ & {$[16,31,32]$} \\
\hline Atherosclerotic plaque preparation ${ }^{a}$ & $\begin{array}{l}50-160 \mathrm{mg} \\
\text { wet weight } / \mathrm{mL}\end{array}$ & GPIb, GPVI, $\alpha_{2} \beta_{1}$ & $300-1700$ & $4-5$ & {$[17,33-35]$} \\
\hline Extracellular matrix & n.d. & n.d. & $300-1700$ & $4-5$ & {$[6,16,36]$} \\
\hline
\end{tabular}

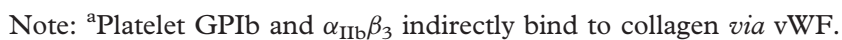

${ }^{b}$ vWF-binding peptide.

describe protocols on how to perform blood flow experiments, and how to record and analyze microscopic images. Where appropriate, we explain differences in the use of human, mouse, or rat blood. In addition, we discuss frequent experimental problems and artifacts, and we describe the use of flow chambers for monitoring the effects of antiplatelet drugs.

\section{Thrombogenic surfaces in flow chamber assays}

Both custom-made and commercial flow devices need to be pre-coated with thrombogenic components to achieve platelet adhesion and aggregation under flow conditions. In Table I, an overview is given of substrates available for coating and the corresponding platelet receptors, while Box 1 provides a guide for preparing coated flow chambers.

\section{Collagens and related surfaces}

The fibrillar collagens, types I and III, are highly platelet-adhesive and thus can act as suitable substrates in whole-blood flow assays (Table I). Both collagens bind von Willebrand factor (vWF) from blood plasma, and serve as ligand for the two platelet collagen receptors, glycoprotein (GP)VI, and integrin $\alpha_{2} \beta_{1}[11,37,38]$. The collagen-bound vWF captures platelets at high-shear flow, via initially GPIb-V-IX and subsequently integrin $\alpha_{\mathrm{IIb}} \beta_{3}[22,39$, 40]. Since platelet-collagen interaction via GPVI causes secretion, integrin activation, and procoagulant activity, coated collagens are capable to induce the whole process of thrombus formation within a time period of several minutes [3, 12, 41]. Most active in promoting thrombus formation are those preparations of type I collagen, which form large fibers and thereby strongly activate GPVI. In general,
Box 1. Protocol for preparation of custom-made and commercial flow chamber devices.

- Use devices with parallel-plate flow chambers, which are appropriately cleaned and blocked.

- Preferably coat one side of the chamber with thrombogenic material of interest. Note: precise control is possible by coating a glass coverslip that can be mounted onto the chamber. In this case, the following procedure can be used:

- degrease coverslips with $2 \mathrm{M} \mathrm{HCl}$ in $50 \%$ ethanol, then wash with milli-Q water;

- apply the coating material at the coverslip in a humid atmosphere. Note: pipetting of $2 \mu \mathrm{L}$ solution (e.g., collagen $50 \mu \mathrm{g} / \mathrm{mL}$ ) gives coated spots of $>2 \mathrm{~mm}$ in diameter;

- allow the coating material to adhere for 30-60 min. Prevent drying out of coated proteins. Note: for collagen, allow fibrils to be formed at neutral $\mathrm{pH}$ in a humid box;

- remove non-bound coating proteins by wash with appropriate rinsing medium (e.g., saline).

- Block coated surfaces with BSA-containing isotonic buffer medium (e.g., modified Tyrode's buffer $\mathrm{pH} 7.45$, consisting of $136 \mathrm{mM} \mathrm{NaCl}, 10 \mathrm{mM}$ glucose, $5 \mathrm{mM}$ Hepes, $2.7 \mathrm{mM} \mathrm{KCl}$, $2 \mathrm{mM} \mathrm{MgCl}_{2}, 2 \mathrm{mM} \mathrm{CaCl} 2,1 \% \mathrm{BSA}$ ).

- Connect tubing to the flow device if needed. Note: shortly before starting blood flow, check that the assembled flow system is leak-tight.

- Rinse the assembled system with isotonic buffer. Add anticoagulant (e.g. heparin $1 \mathrm{U} / \mathrm{mL}$ ) to prevent coagulation, if required.

- Carefully check the assembled system for absence of air bubbles. Note: air bubbles may be formed in buffers due to temperature changes.

type III collagens have a lower thrombogenic activity. Precise recommendations on the use of collagen surfaces for flow assays have been given in an SSC communication [42].

When coated alone, vWF again interacts with platelets via GPIb-V-IX and $\alpha_{\mathrm{IIb}} \beta_{3}$ at high shear rate $\left(>800 \mathrm{~s}^{-1}\right)$, and establishes membrane tether formation and platelet arrest [23, 39]. However, large thrombi with platelet aggregates are not formed on 
vWF surfaces, unless experiments are carried out at very high shear rates $\left(>10000 \mathrm{~s}^{-1}\right)$ [41]. Surfaces coated with anti-vWF mAb bind vWF from plasma, and are similarly effective as coated vWF [24].

Immobilized synthetic collagen-like peptides provide a recent alternative for the use of native fibrillar collagens in flow assays, allowing studying platelet adhesion under flow via specific collagen receptors (Table I). Peptides containing the amino acid motif GPRGQOGVMGFO bind vWF, peptides with the sequence GFOGER interact with platelet integrin $\alpha_{2} \beta_{1}$, while peptides containing multiple GPO residues interact with platelet GPVI [19, 20]. Interestingly, these collagen-like peptides can also be used in combinations, or together with vWF.

\section{Non-collagen and complex surfaces}

Also non-collagen components present in the vasculature support platelet adhesion and thrombus formation, when coated in a flow chamber, though mostly at shear rates $<800 \mathrm{~s}^{-1}$ (Table I) [43, 44]. Flowed platelets adhere to coated fibrinogen and fibronectin via integrins $\alpha_{\mathrm{IIb}} \beta_{3} / \alpha_{\mathrm{v}} \beta_{3}$ and $\alpha_{5} \beta_{1}$, respectively $[25,26]$. Coated laminin mediates platelet adhesion via integrin $\alpha_{6} \beta_{1}$ [31]. Such surfaces support the adhesion of only single platelets, except when coagulation is introduced and fibrin-containing thrombi are formed [27, 45]. Fibrin-coated surfaces trap vWF and mediate platelet adhesion in a GPIbdependent but $\alpha_{\mathrm{IIb}} \beta_{3}$-independent fashion [28-30].

More complex physiological coatings, representing a damaged arterial wall, have been used for flow perfusion studies. Examples are isolates from atherosclerotic plaques or the endothelial-derived extracellular matrix, where collagen and $\mathrm{vWF}$ appear to be the most active components for thrombus formation $[16,17,33,34]$.

An interesting development is the use of microarrays with various collagen or non-collagen surfaces that are machine-coated on flow-chamber coverslips, so that thrombus formation can be assessed as a function of the surface within one run [46].

\section{Flow chamber equipment and control of blood flow}

Dedicated, well-designed equipment is needed for reproducible and standardized flow assays. Here, we discuss the use of flow devices constructed as parallel-plate chambers.

\section{Custom-made and commercial parallel-plate} flow chambers

Several types of parallel-plate flow chambers and microcapillaries, both non-commercial and commercial (e.g., Ibidi, Venaflux, Bioflux, and Glycotech) are now in routine use to assay thrombus formation with human, mouse, or rat blood. Specific advantages and disadvantages of the most common chamber devices have recently been listed [10]. In contrast to the early flow chambers, which required relatively large volumes of blood [6, 7], current chamber types are smaller in size and operate with smaller blood volumes, flowed in single pass. It is beyond the scope of this article to describe the differences between individual custom-made and commercial flow chamber devices. Such information is provided elsewhere [4, 5]. Here, we focus on common aspects of the reproducible use of parallelplate type flow chambers.

\section{Chamber preparation and assembly}

Similar types of precautions need to be taken for successful use of the various (commercial) flow chambers. As an example, we will concentrate here on the use of the device manufactured in our institute. It consists of a transparent polycarbonate block in which a rectangular space is engraved with a width of 3.0 or $5.0 \mathrm{~mm}$ and a depth of 50 or $100 \mu \mathrm{m}$ (Figure 1a). At the inlet and outlet sides of the flow chamber space, tubes are drilled at an angle of $20^{\circ}$ $(1.5 \mathrm{~mm}$ diameter) to prevent flow perturbations during blood inflow. The block is mounted onto a glass coverslip that can be pre-coated with collagen or other thrombogenic material and provide the biologically active side of the chamber. An aluminum holder containing two self-tapping bolts serves to clamp chamber block and coverslip together in a leak-free way (Figure 1b).

If flow chambers with coverslips are used, these need to be assembled in such a way that leakage does not occur. Options for preventing leakage are the use of clamps, a vacuum system, or glue. Many systems work with small tubing (inner diameter $1 \mathrm{~mm}$ ), that is connected to the chamber end. The assembled system needs to be rinsed with bovine serum albumin (BSA) containing buffer to block uncoated parts of the chamber surface and prevent non-specific platelet adhesion and contact activation of the coagulation system (Box 1). Furthermore, it needs to be rigorously checked for the absence of air bubbles. When pre-mixing of blood with another fluid is needed, a convenient solution is to use $y$-shaped tubing, whose outlets can be connected to two syringes, so that the mixing occurs immediately before blood entry into the chamber.

Some (commercial) flow chamber devices are already pre-assembled and these, hence, must be coated by incubation of the closed chamber system with the thrombogenic material of interest. Once appropriately assembled and blocked (Box 1), 


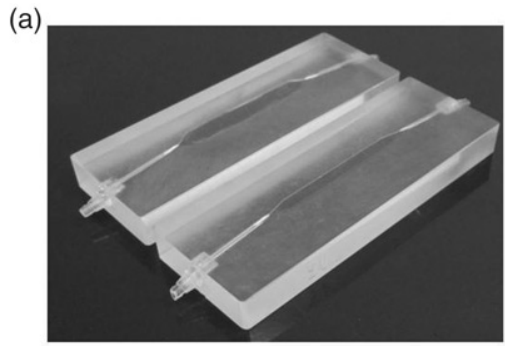

(c)

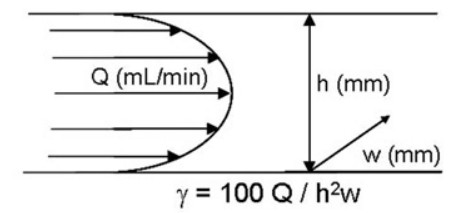

(b)

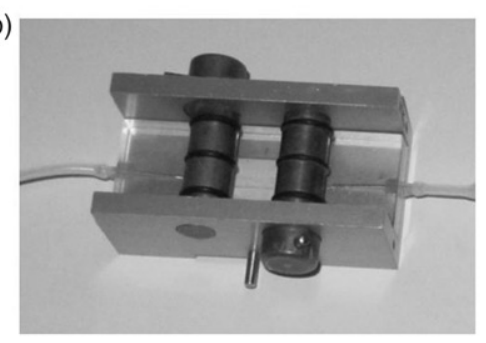

(d)

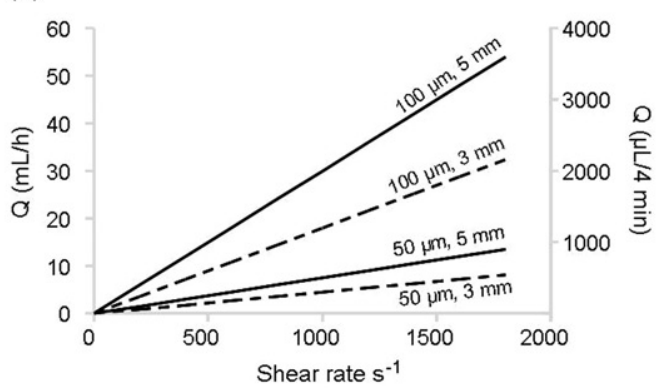

Figure 1. Custom-made flow chamber and blood volume required for measuring thrombus formation. (a) Two parallel-plate flow chambers with channels (height $h=50 \mu \mathrm{m}$ and width $w=5$ or $3 \mathrm{~mm}$ ) engraved in polycarbonate blocks. Note the $20^{\circ}$ angled inlet and outlet for connection to tube. (b) Aluminum holder with bolts for leak-tight attachment of a coverslip to the flow-chamber block (Maastricht Instruments, Maastricht). (c) Equation, assuming a parabolic flow pattern, for calculating the chamber wall-shear rate $\gamma$ from the flow rate $Q$ of blood. (d) Blood volumes required for perfusion at indicated shear rates through chambers with indicated dimensions in height $(50-100 \mu \mathrm{m})$ and width $(3-5 \mathrm{~mm})$. Blood consumption is shown in both $\mathrm{mL} / \mathrm{h}$ and $\mu \mathrm{L} / 4 \mathrm{~min}$.

the coated flow chamber system is ready for blood perfusion.

\section{Regulation of blood flow and perfusion pumps}

Assuming a parabolic flow pattern, the shear rate $\gamma$ of flowing blood in a parallel-plate chamber is described by the equation, $\gamma=100 Q / h^{2} w$ (Figure 1c), provided that the chamber width exceeds the height by far [4]. Herein, $Q$ is the volumetric flow rate $(\mathrm{mL} / \mathrm{min}), h$ the chamber height $(\mathrm{mm})$, and $w$ the chamber width $(\mathrm{mm})$, while the shear rate $\gamma$ is expressed in inverse seconds $\left(\mathrm{s}^{-1}\right)$. The shear stress $(\tau)$ is obtained from the viscosity $(\eta)$ and shear rate $(\gamma)$, as $\tau=\eta \times \gamma$. Obviously, the dimensions of a parallel-plate flow chamber determine the volume of blood that is needed for a particular flow and shear rate inside the chamber (Figure 1d). For example, for a chamber of depth $50 \mu \mathrm{m}$ and width $3.0 \mathrm{~mm}$, a volume of $300 \mu \mathrm{L}$ blood is required for a $4-\mathrm{min}$ perfusion at $1000 \mathrm{~s}^{-1}$.

These calculations assume that blood acts as a Newtonian fluid. In reality, blood viscosity changes with the flow rate and even within the flow chamber, as the red blood cells are directed toward the center of the blood stream, forming a layer of plasma and platelets near the chamber wall [4]. For practical purposes, this means that the presence of red cells is required for maximal adhesion of flow platelets to the coated chamber wall (hematocrit $>20 \%$ ). Another characteristic of blood flow in small chambers is that, once multi-platelet thrombi are formed, these partly obstruct the chamber lumen and thus alter the local shear rate and flow pattern. In other words, undisturbed parabolic flow patterns will only exist in the initial phase of thrombus formation.

For the control of the blood flow rate in a chamber, high-precision pulse-free perfusion pumps are available, which can operate with one or two syringes in pushing or pulling mode. An advantage of pushing a syringe filled with blood is that leakage and appearance of air bubbles can better be controlled, but a disadvantage is the need of syringe replacement after blood flow, which increases the chance of manual contact with blood. One advantage of syringe pulling is that blood can be pipetted into a reservoir, from which it is drawn through the flow chamber. Clearly, this requires that the system is completely leak-tight. Blood perfusion in most laboratories is performed at constant flow rate, but incidentally step-wise changes in flow rate are introduced, e.g., to determine aggregate stability [9] or provoke coagulation [47].

\section{Use of microscopes}

With suitably designed (transparent) flow devices, the process of thrombus formation can be monitored by brightfield as well as fluorescence microscopy. Brightfield microscopic images can be captured with 
a microscope-attached digital charged coupled device camera, preferably in combination with phase-contrast or differential interference contrast enhancement [48]. For sensitive detection of fluorescence, a high-numerical aperture (oil) objective is required, given the small size of platelets. Both nonconfocal (lamp or led) and confocal (one or more lasers) microscopes are suited for fluorescence imaging of a thrombus, but confocal microscopes have the advantage that $z$-stacks of images can be captured, e.g., to measure the thrombus volume [20]. Many laboratories run flow-perfusion experiments at room temperature [10], as this does not require a temperature-controlled stage.

\section{Control of blood anticoagulation for flow chamber assays}

Stringent control of blood coagulation is needed for reproducible flow assays. The choice is to either fully prevent the coagulation process or trigger it in a controlled way.

\section{Flow assays in the absence of coagulation}

In studies focusing on platelet function, coagulant activity in the flow chamber should be prevented completely. Since platelet adhesion and aggregation are dependent on the concentrations of free $\mathrm{Mg}^{2+}$ and $\mathrm{Ca}^{2+}$, the common choice is to draw blood into an anticoagulant medium that maintains physiological, millimolar concentrations of these divalent cations, instead of citrate [49]. To prevent coagulation and fibrin formation in the flow chamber, a combination of anticoagulants is needed. Detailed procedures of how to collect blood are described in Box 2. Human and rat blood can well be collected into PPACK (d-phenylalanyl-1-prolyl-1-arginine chloromethyl ketone) or hirudin, supplemented with low-molecular weight heparin (inhibiting factor Xa). Mouse blood is collected into PPACK plus heparin (Sigma grade I-A). As an unstable chloromethyl ketone, PPACK is gradually consumed in the blood, and it needs to be re-added after a certain time.

Several other precautions can be made to suppress residual coagulation (Box 2). A short incubation of drawn blood samples at $37^{\circ} \mathrm{C}$ will inactivate autocrine ADP and traces of thrombin and lead to resensitization of the platelets. The composed flow chamber system should be rinsed with buffercontaining anticoagulant (e.g. heparin), for inhibiting the contact activation pathway of coagulation.

For some purposes, human citrate-anticoagulated blood has been used in flow chamber studies without recalcification. In such experiments, thrombi formed on a collagen surface are more
Box 2. Protocol for flow perfusion assays in the absence of coagulation.

- Collect blood into suitable anticoagulant medium. Insure that coagulation is fully prevented. Re-rinse the collection system with anticoagulant medium, and check for proper mixing of blood and this medium. Note: continuous blood flow is a good indication for absence of coagulation:

- for human blood, draw with large 23 gauge needle to insure undisturbed flow. Use PPACK $(400 \mu \mathrm{M}$ in saline, $1: 10)$ or hirudin $(200 \mathrm{U} / \mathrm{mL}$ in saline, $1: 10)$ as anticoagulant. When appropriate, add low-molecular weight heparin $(5 \mathrm{U} / \mathrm{mL})$ or platelet inhibitor;

- for mouse blood, if possible collect by retro-orbital or vena cava puncture. Use PPACK ( $400 \mu \mathrm{M}$ in saline, 1:10) plus (low molecular weight) heparin $(5 \mathrm{U} / \mathrm{mL})$ as anticoagulants;

- for rat blood, collect by aortic puncture. Use same anticoagulants as for human blood.

- Incubate the collected blood at $37^{\circ} \mathrm{C}$ for $10-15 \mathrm{~min}$ to resensitize platelets. Store then at room temperature. Note: use human or rat blood within $3 \mathrm{~h}$ (in case of PPACK blood, re-add $10 \mu \mathrm{M}$ PPACK after $1 \mathrm{~h}$ ); use mouse blood within $1 \mathrm{~h}$.

- Preferentially check collected blood for normal platelet count. Note: a low platelet count points to platelet activation via autocrine ADP or traces of thrombin.

- Add desired (ant)agonist, fluorescent probe, or vehicle buffer. Note: platelet adhesion under flow is influenced by DMSO or ethanol $(0.3 \%)$, sodium azide $(15 \mu \mathrm{M})$, or $\mathrm{Ca}^{2+}$-chelating media such as phosphate-buffered saline.

- Fill syringe or inlet part of the flow chamber with requested volume of blood. Note: when using a syringe, prevent the formation of air bubbles at connection points with the chamber.

- For perfusion experiments in pushing mode, place syringe with blood on perfusion pump and start blood flow; for experiments in pulling mode, connect tubing to pulling syringe and start the blood flow. Note: check for a regular blood flow and absence of air bubbles.

- Monitor platelet adhesion and thrombus formation by microscopic imaging. Note: at $1000 \mathrm{~s}^{-1}$, platelet should form thrombi on collagen within 4-6 min for human or rat blood, and within 3-4 min using mouse blood.

densely packed with highly activated platelets in comparison to perfusion at high levels of divalent cations. The likely explanation is that the relatively low $\mathrm{Ca}^{2+}$ level supports human platelet integrin activation [49].

One of the earliest indications of insufficient anticoagulation is a drop in whole-blood platelet count. In blood perfusion through a flow chamber, this is detected as the incidental passing and adhesion of a 'white' platelet-fibrin clot (Figure 2c). At a later stage, flowing red blood cells adhere to the chamber surface, possibly interacting with locally formed fibrin fibers, while platelet adhesion diminishes (Figure 2d). This stage is quickly followed by the appearance of multiple platelet-fibrin clots (Figure 2e) and the formation of fibrin fibers (Figure 2f), especially at sites of flow disturbances within the chamber. Formation of air bubbles should be prevented, since these cause immediate necrosis 
(a)

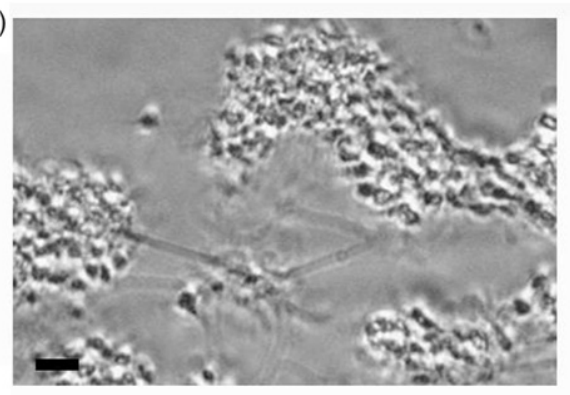

(c)

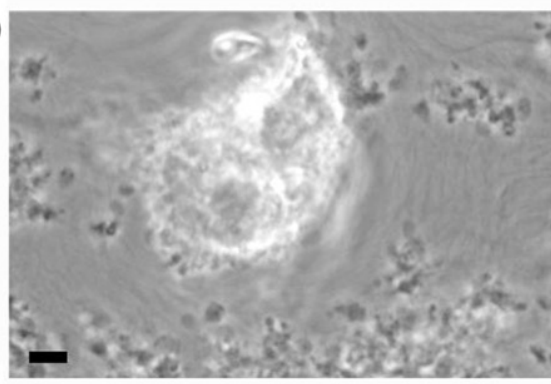

(e)

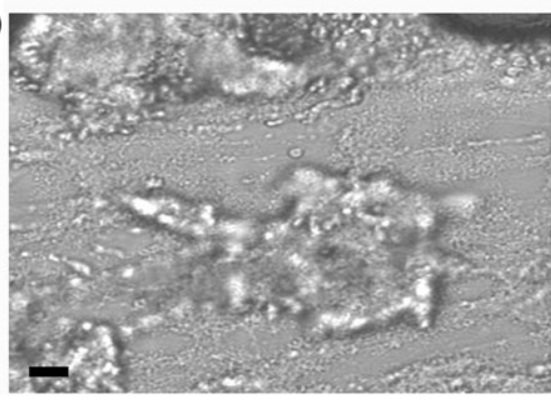

(b)

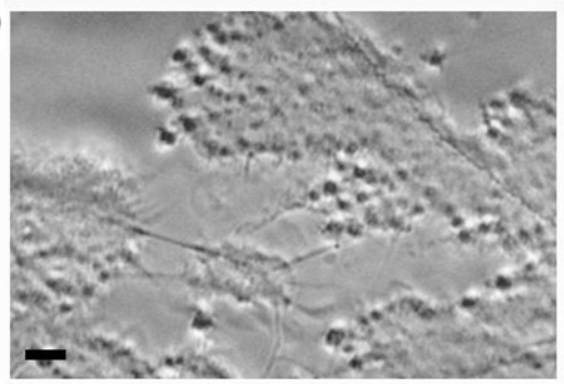

(d)

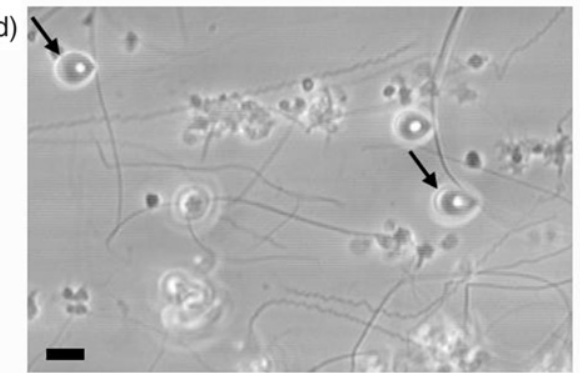

(f)

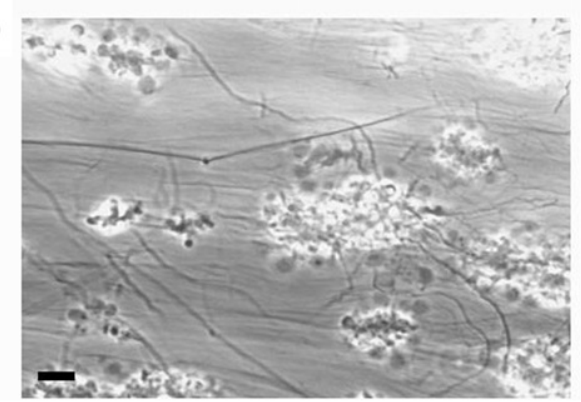

Figure 2. Experimental artifacts resulting in abnormal thrombus formation in parallel-plate flow chambers. Disturbing, necrotic effect of air bubbles. Human thrombi formed on a collagen surface before (a) and after (b) passage of an air bubble. Initial signs of coagulation due to poor action of anticoagulants. Platelet-fibrin clot formed in human blood and trapped on a collagen surface (c); and adhesion of red blood cells (arrows) with few platelets at sites of fibrin formation (d). Signs of poorly controlled coagulation of human blood. Local formation of large platelet-fibrin clots (e); and fibrin fibers between aggregated platelets (f). Bars $=10 \mu \mathrm{m}$.

of adhered platelets (Figure 2a and b), which then trigger the coagulation process. Important to realize is, that after one or more hours (depending on the species and anticoagulant type), blood samples may contain such high levels of activated coagulation factors, that clot formation in the chamber can no longer be prevented.

\section{Flow assays in the presence of coagulation}

Given the interdependency of platelet and coagulation activation and the role of fibrin in thrombus formation [50,51], there is increasing interest in performing flow chamber assays in the presence of coagulation $[27,34,52]$. One way of achieving this is by mixing citrate-anticoagulated human, rat, or mouse blood with $\mathrm{CaCl}_{2} / \mathrm{MgCl}_{2}$ medium just before it enters the flow chamber (Box 3). If recalcified blood is flowed over a collagen surface, coagulation is stimulated via the intrinsic pathway of collagen-induced factor XII activation, while GPVI signaling results in the formation of procoagulant platelets [52]. By adding tissue factor to the recalcification medium, the extrinsic coagulation pathway can be stimulated as well [27, 53]. Another possibility is to immobilize tissue factor on the surface [54].

\section{Real-time and end-stage measurements of thrombus formation in flow chambers}

Thrombus formation under flow can be followed, not only by brightfield imaging, but also with a whole range of fluorescent probes, the majority of which are suited for human, mouse, and rat blood (Table II). In this section, we describe staining procedures to measure aspects of thrombus formation in real time during flow and as end stage after the flow experiment. 
Box 3. Protocol for flow perfusion assays in the presence of coagulation.

- Collect blood into trisodium citrate $(129 \mathrm{mM}, 1: 10)$. Insure that coagulation is fully prevented. Pre-rinse the collection system with anticoagulant medium, and check for proper mixing of blood and this medium. Note: continuous blood flow is a good indication for absence of coagulation:

- for human blood, draw with large 23 gauge needle to insure undisturbed flow.

- for $\underline{\text { mouse blood }}$, if possible collect by retro-orbital or vena cava puncture.

- for rat blood, collect by aortic puncture.

- Check that right volume of citrate anticoagulant is added. Then, incubate the blood at $37^{\circ} \mathrm{C}$ for $10-15$ min to resensitize platelets.

- If possible, check for a normal platelet count. Preferentially store blood at room temperature. Note: a low platelet count points to platelet activation via autocrine ADP or traces of thrombin.

- Add desired (ant)agonist, fluorescent probe, or vehicle buffer. Note: platelet adhesion under flow is influenced by DMSO or ethanol $(0.3 \%)$, sodium azide $(15 \mu \mathrm{M})$, or $\mathrm{Ca}^{2}+$-chelating media like phosphate-buffered saline.

- Fill a syringe or inlet part of the flow chamber with the requested volume of blood. Fill a second syringe with coagulation buffer, consisting of $75 \mathrm{mM} \mathrm{CaCl}_{2}$ and $37.5 \mathrm{mM} \mathrm{MgCl}_{2}$. If required, add $10 \mathrm{pM}$ tissue factor.

- Connect both syringes to $y$-shaped inlet tubing that is connected directly before the flow chamber. Check for absence of air bubbles.

- Place syringes on perfusion pumps (pushing mode), and start mixing nine volumes of blood with one volume of coagulation buffer. Check for regular blood flow and for absence of leakage or air bubbles. Note: check that the mixing occurs well.

- Monitor thrombus and fibrin formation by microscopic imaging. Note: at $1000 \mathrm{~s}^{-1}$ platelet should form thrombi with fibrin within 5-8 min in case of human, rat, or mouse blood.

- Make sure that blood flow does not stop, as this may facilitate fibrin formation and occlusion of the flow chamber.

Table II. Parameters of whole blood thrombus formation as measured with brightfield and fluorescence microscopy. Brightfield illumination preferentially is with contrast-enhancing optics, such as phase-contrast or differential interference contrast. Indicated fluorescent probes can be used with human, mouse, or rat blood, but monoclonal antibodies (mAb) are for use with human blood only, except where indicated otherwise. Probes with excitation wavelength other than $\sim 488 \mathrm{~nm}$ are not indicated.

\begin{tabular}{|c|c|c|}
\hline Parameter & Brightfield and fluorescent probe & Refs. \\
\hline \multicolumn{3}{|l|}{ Real time measurement } \\
\hline Transient and stable platelet adhesion & Brightfield, calcein, $\mathrm{DiOC}_{6}$ & {$[22,38,55-57]$} \\
\hline Platelet $\mathrm{Ca}^{2+}$ rises & Fluo-3, Fluo-4, OG-BAPTA-1/Fura-red & {$[13,38,58-61]$} \\
\hline Platelet shape change and tether formation & Brightfield, $\mathrm{DiOC}_{6}$ & {$[23,56,62]$} \\
\hline Thrombus buildup and contraction & FITC anti-GPIb mAb, calcein, DIOC $_{6}$ & {$[12,55,63-65]$} \\
\hline Thrombus stability (embolization) & Brightfield, $\mathrm{DiOC}_{6}$ & {$[55,66-68]$} \\
\hline Fibrin fiber and clot formation & Brightfield, OG-fibrinogen & {$[34,47,69,70]$} \\
\hline \multicolumn{3}{|l|}{ End stage measurement } \\
\hline Platelet surface area coverage & Brightfield, $\mathrm{DiOC}_{6}$ & {$[11,20,56,61]$} \\
\hline Platelet aggregate size & Brightfield, $\mathrm{DiOC}_{6}$ & {$[12,20,52]$} \\
\hline $\begin{array}{l}\text { Thrombus volume } \\
\text { (confocal laser scanning) }\end{array}$ & FITC anti-GPIb mAb, $\mathrm{DiOC}_{6}$ & {$[20,55,63,70]$} \\
\hline Platelet integrin $\alpha_{\mathrm{IIb}} \beta_{3} / \alpha_{2} \beta_{1}$ activation & $\begin{array}{l}\text { FITC PAC1 / FITC IAC1 mAb, } \\
\text { FITC JON/A mAb }{ }^{\mathrm{a}} \text {, OG-fibrinogen }\end{array}$ & {$[12,48,71]$} \\
\hline Platelet P-selectin exposure & FITC anti-CD62 mAb & {$[48,60,72]$} \\
\hline Fibrin fiber and clot formation & OG-fibrinogen & {$[34,47,52,54,69]$} \\
\hline Platelet phosphatidylserine exposure & OG-annexin A5 & {$[13,14,48,61]$} \\
\hline Platelet coagulation factor binding & OG-prothrombin, OG-factor Xa, OG-factor Va & {$[47,48,52]$} \\
\hline
\end{tabular}

Note: DiOC $_{6}, 3,3$ '-dihexyloxacarbocyanine iodide; OG, Oregon green 488; and FITC, fluorescein isothiocyanate.

${ }^{\mathrm{a}}$ For use with mouse blood.

\section{Real-time measurement of platelet adhesion and $\mathrm{Ca}^{2+}$ response}

Platelet adhesion under flow can be observed from recorded time series of brightfield images, but more easily from series of fluorescence images $[22,38,55-57]$. In the latter case, platelets in the blood need to be labeled in such a way that the background fluorescence of plasma is low. This can be achieved by adding to the blood a label which binds to platelets with high-affinity, examples being antibodies against surface proteins such as GPIb [55] or specific membrane probes such as $\mathrm{DiOC}_{6}$ [56]. Alternatively, the platelets can be isolated and prelabeled, e.g., with $\mathrm{Ca}^{2+}$ probe, and after a centrifugation step, re-added to the blood sample [38].

In human, rat, or mouse platelets loaded with the $\mathrm{Ca}^{2+}$ probe, Fluo-4 (or Fluo-3), flow-dependent adhesion can directly be compared with the $\mathrm{Ca}^{2+}$ response [13, 27, 38]. To monitor the $\mathrm{Ca}^{2+}$ responses in single platelets, a sensitive 
(a)

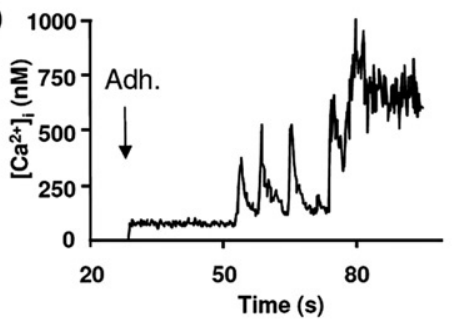

(c)

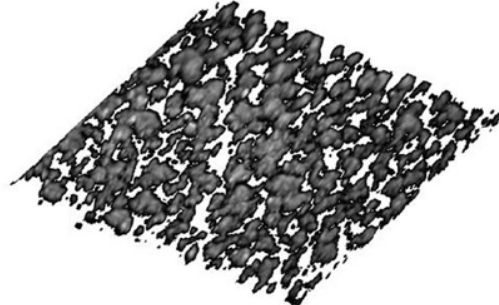

(e)

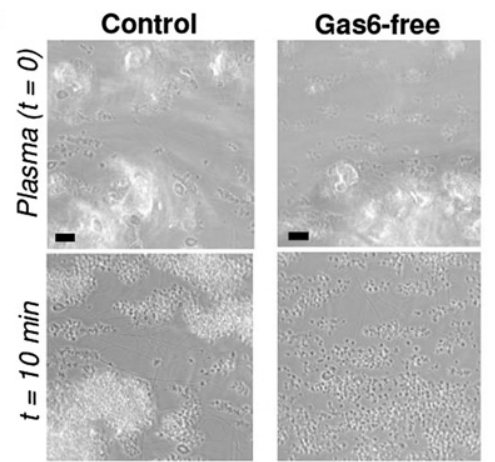

(b)

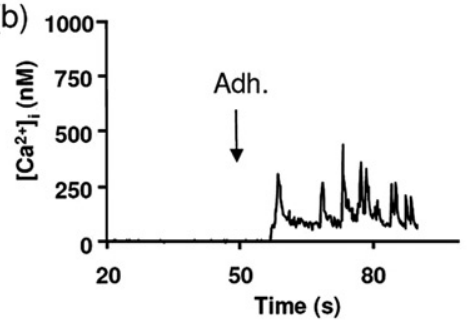

(d)

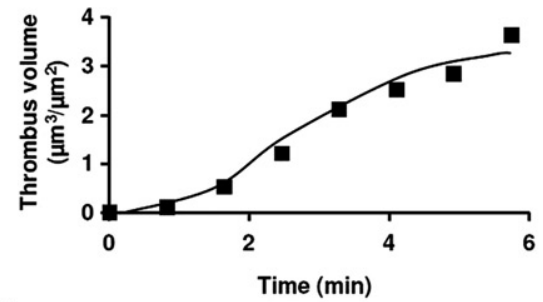

(f)

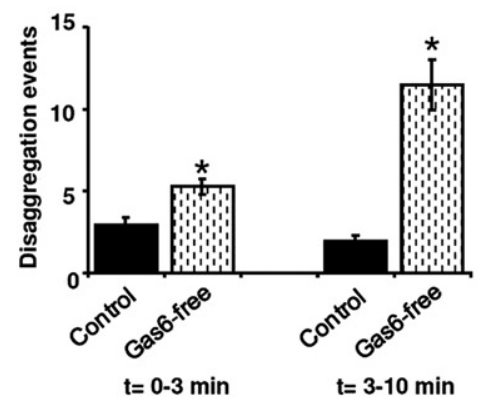

Figure 3. Real-time measurement of thrombus formation. Typical $\mathrm{Ca}^{2+}$ rises of single Fluo-3-loaded platelets during high-shear flow of human blood, which either (a) stably adhere to collagen or (b) transiently adhere to vWF. Measurement of thrombus volume during perfusion of human blood with $\mathrm{DiOC}_{6}$-labeled platelets $\left(1000 \mathrm{~s}^{-1}\right.$, collagen surface). 3D reconstruction of image stack after $4 \mathrm{~min}$, recorded by confocal microscopy (c); time-dependent increase in thrombus volume calculated from image stacks (d). Disaggregation of human platelets from thrombi on collagen during post-perfusion with control or Gas6-free plasma. Phase-contrast images before and after $10 \mathrm{~min}$ of post-perfusion (e); quantification of disaggregation events in the first $3 \mathrm{~min}$ and the next $7 \mathrm{~min}$ (f). Modified from Ref. [67], ${ }^{\star} p<0.05 v s$. control.

shutter-controlled fluorescence imaging system is needed, capable to take images of Fluo-4 fluorescence at a relatively high speed $(2 \mathrm{~Hz})[58]$. Figure 3 shows some typical $\mathrm{Ca}^{2+}$ traces, i.e., a prolonged $\mathrm{Ca}^{2+}$ rise of a platelet stably adhering to collagen (Figure 3a) and a spiking $\mathrm{Ca}^{2+}$ rise of a cell transiently adhering to vWF (Figure $3 b$ ).

Procedures have been developed to analyze the changes in fluorescence in single, adhered platelets [58]. Herein, traces of changes in fluorescence intensity $(F)$ of regions-of-interest, each representing one platelet, are converted into traces of nanomolar levels of $\mathrm{Ca}^{2+}$. Briefly, after background subtraction, per region-of-interest, a baseline fluorescence value $F_{0}$ is determined, which is used for calculation of the pseudo-ratio $F^{\prime}=F / F_{0}$. Concentrations of $\left[\mathrm{Ca}^{2+}\right]_{i}$ in nanomolar are obtained from the equation $\left[\mathrm{Ca}^{2+}\right]_{i}=K_{d} \bullet F^{\prime} /\left(F_{\max }^{\prime}-F^{\prime}\right)$, where $K_{d}$ is the dissociation constant of the fluorescent probe and $F_{\text {max }}^{\prime}$ the maximal value of a nanospot of $\mathrm{Ca}^{2+}$-bound fluorescent probe. An alternative procedure is to calculate fluorescence ratio values from platelets loaded with two probes exciting at different emission wavelengths, OG-BAPTA-1 and Fura-red [59]. Note that the conventional dual-excitation $\mathrm{Ca}^{2+}$ probe Fura-2 cannot be used here, because of the high background fluorescence of blood plasma at $340 \mathrm{~nm}$ excitation.

\section{Real-time measurement of platelet shape and thrombus stabilization}

Adhered platelets in a flow chamber are subjected to high shear forces, and can undergo marked changes in shape, e.g., by producing membrane tethers as long as $20 \mu \mathrm{m}$ [23]. Such morphological changes of unlabeled or labeled platelets can be detected by time-lapse microscopy using high-magnification objectives (Table II). The same equipment can monitor platelet aggregation 

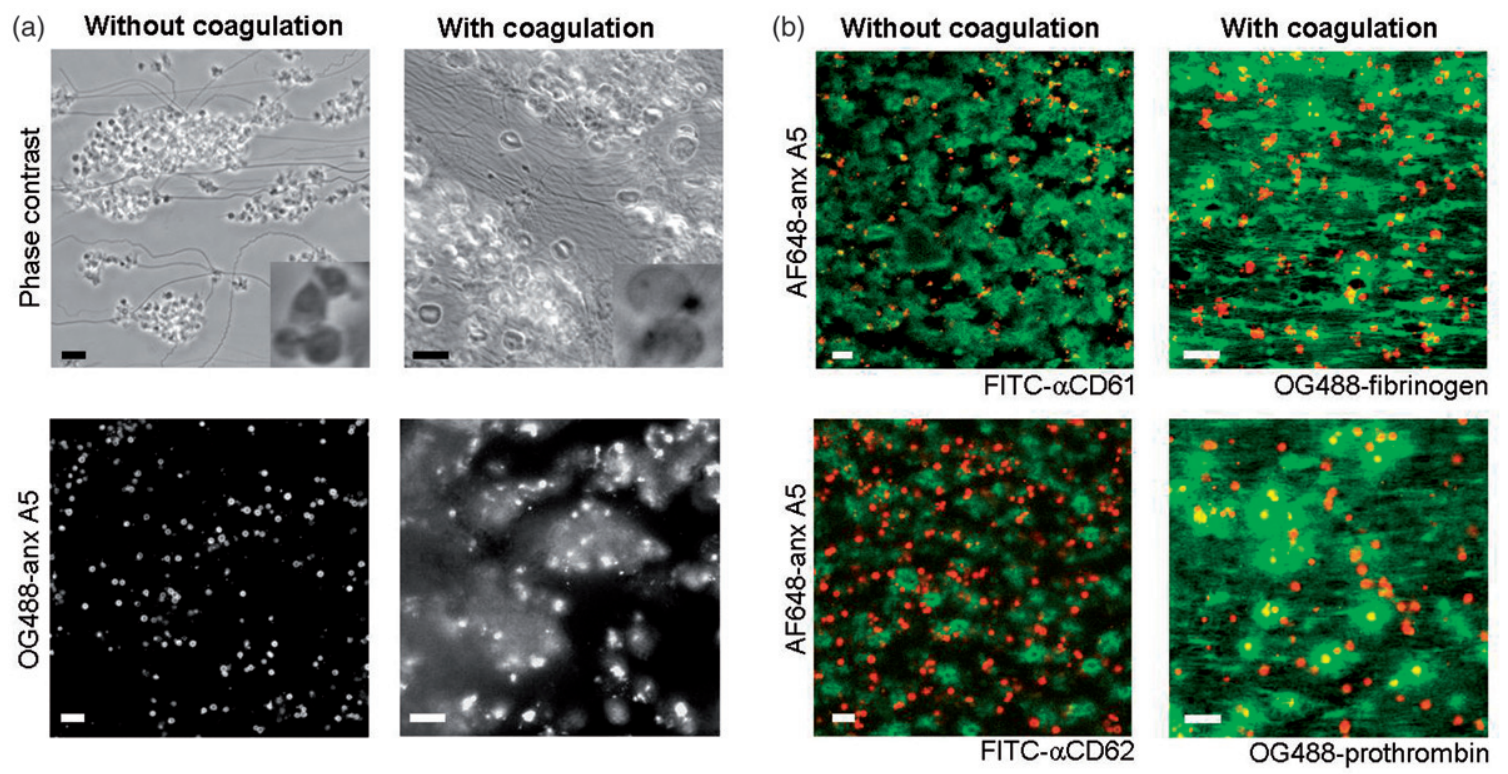

Figure 4. Different platelet responses in thrombus formation without or with coagulation. (a) Human thrombi formed under flow on collagen in the absence of coagulation (PPACK/fragmin-anticoagulated blood). Non-confocal images show collagen-adhered aggregated platelets and single procoagulant platelet staining with OG488-annexin A5. Dual-color confocal images show that the aggregated platelets aggregates stain for integrin $\beta 3$ (CD61) and P-selectin (CD62) in green, while the single platelets bind AF547-annexin A5 in red. (b) Human thrombi formed under flow on collagen in the presence of coagulation (recalcified citrate-anticoagulated blood). Non-confocal images show aggregated platelets and massive coagulation with fibrin fibers. Aggregates are surrounded by patches of OG488-annexin A5staining platelets. Dual-color confocal images show fibrin fibers stained with OG488-fibrinogen or OG488-prothrombin in green, and single procoagulant platelets in red. Modified from Ref. [47]. Bars $=10 \mu \mathrm{m}$.

and thrombus contraction under flow. A common procedure to measure thrombus buildup is continuous fluorescence recording of the accumulation of $\mathrm{DiOC}_{6}$-labeled platelets at a surface. Alternatively, one can record series of $z$-stacks of confocal images of $\mathrm{DiOC}_{6}$ fluorescence [12, 63-65]. In the latter case, three-dimensional (3D) image reconstructions can be made showing the increase in thrombus volume (Figure $3 \mathrm{c}$ and $\mathrm{d}$ ).

At high physiological levels of $\mathrm{Ca}^{2+}$ and $\mathrm{Mg}^{2+}$, platelet thrombi are dynamic structures that can easily fall apart [55]. Thrombus instability is particularly observed, when the platelet receptors for ADP, Gas6, or fibrinogen are non-functional $[35,66,67]$. In such case, the $\alpha_{\mathrm{IIb}} \beta_{3}$ integrins will inactivate and platelet-platelet interactions are reverse. Thrombus instability and embolization can be assessed by time-lapse recording of brightfield or fluorescence images during flow (Figure $3 e$ and $\mathrm{f}$ ). Platelet disaggregation can also be imaged after thrombus formation upon post-perfusion with buffers medium [55, 56]. Another method to monitor disintegration of thrombi is by applying step-wise increases in shear rate during blood flow [9]. Flow chamber studies can furthermore identify shear-dependent platelet-leukocyte interactions [73, 74].

\section{Real-time measurement of coagulation parameters}

Under conditions favoring coagulation (see above), the generation of thrombin and fibrin during flowdependent thrombus formation can be studied by microscopic imaging. Thrombin generation is measured by adding the fluorogenic thrombin substrate, Z-GGR-AMC to the blood, and recording timeseries of fluorescence images at sites of a thrombus under stasis [47]. High amounts of thrombin are generated only after a lag time, once platelets in a thrombus show high rises in $\mathrm{Ca}^{2+}$ and respond to this by contraction $[27,47,52]$. The formation of clots and fibrin fibers can be followed in time by adding labeled fibrinogen $[34,69]$.

\section{End-stage measurements after thrombus formation}

Clear recognition of the thrombi formed in a flow chamber is helped by a short perfusion with rinsing buffer to remove red blood cells. Care should be taken to prevent coagulation (anticoagulant in rinsing buffer) and not to allow platelet disaggregation (short rinse). In addition, the thrombi can be poststained by adding suitable labels to the perfusate. Brightfield and fluorescence images can be taken from representative microscopic windows (Figure 4). 
For end-stage measurements of thrombus volume and platelet aggregate size, the same labels can be used as for real-time assays, e.g., the membrane probe $\mathrm{DiOC}_{6}$. Fluorescent markers are available to assess low and high activation states of platelets in a thrombus. Many of these are suitable for use with human, mouse, and rat blood (Table II). Basically, the same probes can be used as in flow cytometry. Activated $\alpha_{\mathrm{IIb}} \beta_{3}$ is stained with fluorescent-labeled antibodies such as PAC1 (human) or JON/A (mouse), or with fibrinogen (human, mouse, and rat) $[12,48,71]$. Antibodies against P-selectin are available to mark platelet $\alpha$-granule secretion $[48,60$, 72]. Procoagulant platelets, expressing phosphatidylserine, are labeled with fluorescent annexin A5 $[14,48,61]$. Interestingly, the phosphatidylserineexpressing platelets promote fibrin formation, which is also detected with fluorescent-labeled fibrinogen [34, 47, 69]. Coagulant activity is recognized from the binding of fluorescent-labeled coagulation factors to platelets in a thrombus, such as (pro)thrombin, factor Va, and factor Xa [47, 48, 52].

\section{Recording and analysis of microscopic images from flow assays}

Brightfield and fluorescence images from flow studies are to be recorded at well-defined optical and sensitivity settings for reproducible results. Box 4 provides some guidelines for optimal microscopic image recording and analysis. Several software packages are available for image analysis using semi-automatic pattern recognition, most popular being ImageJ, Metamorph, and ImagePro [10]. En-face brightfield contrast images provide only two-dimensional information of the thrombi formed. Yet, analyzing such images for surfacearea-coverage is a useful surrogate measure for overall platelet deposition $[13,53,61]$. The surface area coverage usually correlates with thrombus volume, if the platelets on the surface are assembled in (contracted) thrombi with a pyramidal structure. On the other hand, when platelets are present as single structures or platelet aggregates are unstable, a high surface-area-coverage can be obtained at limited thrombus formation. In this case, procedures are available to determine the average size of aggregates by morphometric analysis of individual features on the surface $[20,55,61]$.

Specific analysis tools have been developed to measure thrombus volume from $z$-stacks of recorded fluorescence images $[12,20]$. An elegant way is to calculate the sum of the surface-area-coverage of all images in a stack, and multiply this with the stack distance. Dividing this value by the field area results in a measure of thrombus formation (in units of
Box 4. Protocol for microscopic image recording and analysis.

- During the flow of human, mouse, or rat blood, record brightfield and/or fluorescence images with camera or laser scanner, as required. Note: for recording clear brightfield images, flow chambers preferentially have a depth of $50-100 \mu \mathrm{m}$.

- At predefined end point, change from perfusion with blood to perfusion with rinsing buffer (e.g. modified Tyrode's buffer). If required, add fluorescent probe to the rinsing buffer. Note: prevent fluid stasis, since this may cause fibrin formation.

- Record brightfield images of the formed thrombi during flow, since rapidly moving erythrocytes will not distort images. Note: capture images before thrombi start to fall apart.

- Record fluorescence images after washing away unbound probe, to reduce background fluorescence. Note: stained thrombi might be fixed for later examination.

- For recording brightfield and fluorescence images, check for optimal settings with respect to:

- optical focality;

- magnification (objective, camera, and zoom);

- phase-contrast or differential interference contrast optics;

- sensitivity and specificity of the fluorescence detection (lamp/laser power and gain, diaphragm, filters, and dichroics);

- homogeneity of fluorescence staining;

- low background fluorescence.

- Record in-focus images from representative areas with thrombi. Prevent photobleaching when recording fluorescence images. Note: in case of rapidly bleaching probes such as fluorescein and phycoerythrin, record from unexposed windows.

- Check the recorded images for focality, homogeneity of illumination or staining, and absence of artifacts (clots, red blood cells, or air bubbles).

- Analyze the recorded images blinded for the condition using appropriate software and semi-automatic macros.

$\mu \mathrm{m}^{3} / \mu \mathrm{m}^{2}$, Figure $3 \mathrm{~d}$ ), which reflects the mean height of all thrombi on the surface [20].

\section{Flow chambers and control of antiplatelet medication}

Current antiplatelet drugs employed in clinical practice are directed against $\mathrm{P} 2 \mathrm{Y}_{12}$ receptors (clopidogrel, previously ticlopidine), integrin $\alpha_{\mathrm{IIb}} \beta_{3}$ (tirofiban, abciximab), or formation of thromboxane $\mathrm{A}_{2}$ (aspirin). These drugs prevent secondary thrombotic events, but their efficacy is not always complete (clopidogrel and aspirin) and they may cause an increased risk of bleeding (tirofiban and clopidogrel/ aspirin) [75-77]. Clinical trials with agents targeting the platelet thromboxane or thrombin receptors are still ongoing [78]. Given the ongoing debate on how to monitor antiplatelet treatment and prevent undesired bleeding, flow chamber-based assays may provide a useful method to answer these questions. Table III summarizes the results from published patient studies regarding effects of antiplatelet medication on whole-blood thrombus formation, using collagen as a surface. It is shown that aspirin intake alone has a variable effect on thrombus formation, 
Table III. Effects of antiplatelet medication on whole blood thrombus formation ex vivo, as obtained with custom-made parallel-plate flow chambers. Cited studies were performed with blood from patients or healthy volunteers.

\begin{tabular}{lllll}
\hline Medication & Coating material & $\begin{array}{c}\text { Overall effect on } \\
\text { thrombus formation }\end{array}$ & \multicolumn{1}{c}{$\begin{array}{c}\text { Stability } \\
\text { of thrombus }\end{array}$} & Refs \\
\hline Aspirin & Collagen I/III & Unchanged/reduced & Variable effect on thrombus stability & [79-83] \\
Aspirin + clopidogrel & Collagen I & Reduced & Instable thrombi & [80, 81] \\
Aspirin + ticlopidine & Collagen I & Reduced & Instable thrombi, normal adhesion & {$[79,81,82]$} \\
\hline
\end{tabular}

while the combination of aspirin and clopidogrel or ticlopidine causes a marked reduction [79-82]. Although limited in number, these studies illustrate the potency of the flow chamber technology in this area.

As described elsewhere, also other flow devices such as the PFA-100 and the IMPACT cone and plate(let) analyzer are able to measure platelet aggregate formation under high-shear conditions [5, 84, 85]. However, these devices give only endpoint values (closure time or final thrombus size, respectively), while flow chamber measurements provide real-time information on a whole panel of output parameters, such as platelet adhesion and activation, thrombus buildup, and fibrin formation/ coagulation, at well-predicted venous $\left(150 \mathrm{~s}^{-1}\right)$ or arterial shear rates $\left(>1500 \mathrm{~s}^{-1}\right)$. The PFA-100 is sensitive for aberrant vWF levels and limitedly for aspirin treatment [84]. Similarly, parallel-plate flow chambers detect $\mathrm{vWF}$ dysfunction in von Willebrand disease types 2 and 3 [86-88].

\section{Conclusions}

Parallel-plate flow chambers are suitable devices for measurement of the process of thrombus formation, as they allow assaying both platelet function and coagulation within the same experiment at predefined shear rates. By combining the flow chamber technology with brightfield and fluorescence microscopy and image analysis, the knowledge on platelet receptors and signaling processes under conditions of low (venous) and high (arterial) shear rates has greatly increased. With the practical information in this methods article, on how to perform reproducible flow chamber assays, we hope to have set a further step forward to the accepted use of this technology in the research laboratory. For implementation in the clinic, a main challenge is to convert current flow chamber devices with complex microscopic monitoring to relatively simple devices with easy and quick read-out.

\section{Acknowledgements}

This study was supported by Zon-MW (11-4000076) and the Center for Translational Molecular Medicine (INCOAG).
Declaration of interest statement: The authors declare that no conflicts of interest exist.

\section{References}

1. Gibbins JM. Platelet adhesion signalling and the regulation of thrombus formation. J Cell Sci 2004;117:3415-3425.

2. Ruggeri ZM, Mendolicchio GL. Adhesion mechanisms in platelet function. Circ Res 2007;100:1673-1685.

3. Munnix IC, Cosemans JM, Auger JM, Heemskerk JW. Platelet response heterogeneity in thrombus formation. Thromb Haemost 2009;102:1149-1156.

4. Zwaginga JJ, Nash G, King MR, Heemskerk JW, Frojmovic M, Hoylaerts MF, Sakariassen KS. Flow-based assays for global assessment of hemostasis. Part 1: Biorheologic considerations. J Thromb Haemost 2006;4: 2486-2487.

5. Zwaginga JJ, Sakariassen KS, Nash G, King MR, Heemskerk JW, Frojmovic M, Hoylaerts MF. Flow-based assays for global assessment of hemostasis. Part 2: Current methods and considerations for the future. J Thromb Haemost 2006, 4:2716-2717.

6. Sakariassen KS, Aarts PA, de Groot PG, Houdijk WP, Sixma JJ. A perfusion chamber developed to investigate platelet interaction in flowing blood with human vessel wall cells, their extracellular matrix, and purified components. J Lab Clin Med 1983;102:522-535.

7. De Groot PG, IJsseldijk MJW, Sixma JJ. Platelet adhesion to the subendothelium under flow. Methods Mol Biol 1999;96: 159-170.

8. Sakariassen KS, Hanson SR, Cadroy Y. Methods and models to evaluate shear-dependent and surface reactivity-dependent antithrombotic efficacy. Thromb Res 2001;104:149-174.

9. Neeves KB, Maloney SF, Fong KP, Schmaier AA, Kahn ML, Brass LF, Diamond SL. Microfluidic focal thrombosis model for measuring murine platelet deposition and stability: PAR4 signaling enhances shear-resistance of platelet aggregates. J Thromb Haemost 2008;6:2193-2201.

10. Roest M, Reininger A, Zwaginga JJ, King MR, Heemskerk JWM, the Biorheology Subcommittee of the SSC of the ISTH. Flow chamber-based assays to measure thrombus formation in vitro: Requirements for standardization. J Thromb Haemost 2011, [Epub ahead of print].

11. Nieswandt B, Brakebusch C, Bergmeier W, Schulte V, Bouvard D, Mohtari-Nejad R, Lindhout T, Heemskerk JW, Zirngibl H, Fässler R. Glycoprotein VI but not a2b1 integrin is essential for platelet interaction with collagen. EMBO J 2001;20:2120-2130.

12. Lecut C, Schoolmeester A, Kuijpers MJ, Broers JL, van Zandvoort MA, Vanhoorelbeke K, Deckmyn H, JandrotPerrus M, Heemskerk JW. Principal role of glycoprotein VI in $\mathrm{a} 2 \mathrm{~b} 1$ and aIIbb3 activation during collagen-induced thrombus formation. Arterioscler Thromb Vasc Biol 2004;24: 1727-1733. 
13. Kuijpers MJ, Schulte V, Bergmeier W, Lindhout $T$, Brakebusch C, Offermanns S, Fassler R, Heemskerk JW, Nieswandt B. Complementary roles of glycoprotein VI and $\mathrm{a} 2 \mathrm{~b} 1$ integrin in collagen-induced thrombus formation in flowing whole blood ex vivo. FASEB J 2003;17:685-687.

14. Bergmeier W, Oh-Hora M, McCarl CA, Roden RC, Bray PF, Feske S. R93W mutation in Orail causes impaired calcium influx in platelets. Blood 2009;113:675-678.

15. Savage B, Ginsberg MH, Ruggeri ZM. Influence of fibrillar collagen structure on the mechanisms of platelet thrombus formation under flow. Blood 1999;94:2704-2715.

16. Wu YP, de Groot PG, Sixma JJ. Shear-stress-induced detachment of blood platelets from various surfaces. Arterioscler Thromb Vasc Biol 1997;17:3202-3207.

17. Cosemans JM, Kuijpers MJ, Lecut C, Loubele ST, Heeneman S, Jandrot-Perrus M, Heemskerk JW. Contribution of platelet glycoprotein VI to the thrombogenic effect of collagens in fibrous atherosclerotic lesions. Atherosclerosis 2005;181:19-27.

18. Zhao XM, Wu YP, Cai HX, Wei R, Lisman T, Han JJ, Xia ZL, de Groot PG. The influence of the pulsatility of the blood flow on the extent of platelet adhesion. Thromb Res 2008; 121:821-825.

19. Munnix IC, Gilio K, Siljander PR, Raynal N, Feijge MA, Hackeng TM, Deckmyn H, Smethurst PA, Farndale RW, Heemskerk JW. Collagen-mimetic peptides mediate flowdependent thrombus formation by high- or low-affinity binding of integrin $\mathrm{a} 2 \mathrm{~b} 1$ and glycoprotein VI. J Thromb Haemost 2008;6:2132-2142.

20. Pugh N, Simpson AM, Smethurst PA, de Groot PG, Raynal N, Farndale RW. Synergism between platelet collagen receptors defined using receptor-specific collagen-mimetic peptide substrata in flowing blood. Blood 2010;115: 5069-5079.

21. Lisman T, Raynal N, Groeneveld D, Maddox B, Peachey AR, Huizinga EG, de Groot PG, Farndale RW. A single highaffinity binding site for von Willebrand factor in collagen III, identified using synthetic triple-helical peptides. Blood 2006;108:3753-3756.

22. Savage B, Saldivar E, Ruggeri ZM. Initiation of platelet adhesion by arrest onto fibrinogen or translocation on von Willebrand factor. Cell 1996;84:289-297.

23. Maxwell MJ, Dopheide SM, Turner SJ, Jackson SP. Shear induces a unique series of morphological changes in translocating platelets: Effects of morphology on translocation dynamics. Arterioscler Thromb Vasc Biol 2006;26:663-669.

24. Elvers M, Stegner D, Hagedorn I, Kleinschnitz C, Braun A, Kuijpers ME, Boesl M, Chen Q, Heemskerk JW, Stoll G, et al. Impaired aIIbb3 integrin activation and shear-dependent thrombus formation in mice lacking phospholipase D1. Sci Signal 2010;3:ra1.

25. Beumer S, IJsseldijk MJ, de Groot PG, Sixma JJ. Platelet adhesion to fibronectin in flow: Dependence on surface concentration and shear rate, role of platelet membrane glycoproteins GP IIb/IIIa and VLA-5, and inhibition by heparin. Blood 1994;84:3724-3733.

26. Zaidi TN, McIntire LV, Farrell DH, Thiagarajan P. Adhesion of platelets to surface-bound fibrinogen under flow. Blood 1996;88:2967-2972.

27. Kuijpers MJ, Nieuwenhuys CM, Feijge MA, Kloots W, Giesen PL, Jerling JC, oude Egbrink MG, Heemskerk JW. Regulation of tissue factor-induced coagulation and platelet aggregation in flowing whole blood. Thromb Haemost 2005;93:97-105.

28. Jen CJ, Lin JS. Direct observation of platelet adhesion to fibrinogen- and fibrin-coated surfaces. Am J Physiol 1991;261:H1457-H1463.
29. Endenburg SC, Hantgan RR, Lindeboom-Blokzijl L, Lankhof H, Jerome WG, Lewis JC, Sixma JJ, de Groot PG. On the role of von Willebrand factor in promoting platelet adhesion to fibrin in flowing blood. Blood 1995;86: $4158-4165$.

30. Keuren JF, Baruch D, Legendre P, Denis CV, Lenting PJ, Girma JP, Lindhout $\mathrm{T}$. von Willebrand factor C1C2 domain is involved in platelet adhesion to polymerized fibrin at high shear rate. Blood 2004;103:1741-1746.

31. Hindriks G, IJsseldijk MJ, Sonnenberg A, Sixma JJ, de Groot PG. Platelet adhesion to laminin: Role of $\mathrm{Ca}^{2+}$ and $\mathrm{Mg}^{2+}$ ions, shear rate, and platelet membrane glycoproteins. Blood 1992;79:928-935.

32. Inoue O, Suzuki-Inoue K, Ozaki Y. Redundant mechanism of platelet adhesion to laminin and collagen under flow: Involvement of von Willebrand factor and glycoprotein IbIX-V. J Biol Chem 2008;283:16279-16282.

33. Penz SM, Reininger AJ, Toth O, Deckmyn H, Brandl R, Siess W. Glycoprotein Ibalpha inhibition and ADP receptor antagonists, but not aspirin, reduce platelet thrombus formation in flowing blood exposed to atherosclerotic plaques. Thromb Haemost 2007;97:435-443.

34. Reininger AJ, Bernlochner I, Penz SM, Ravanat C, Smethurst P, Farndale RW, Gachet C, Brandl R, Siess W. A 2-step mechanism of arterial thrombus formation induced by human atherosclerotic plaques. J Am Coll Cardiol 2011;55:1147-1158.

35. Nergiz-Unal R, Cosemans JM, Feijge MA, van der Meijden PE, Storey RF, van Giezen JJ, oude Egbrink MG, Heemskerk JW, Kuijpers MJ. Stabilizing role of platelet P2 $\mathrm{Y}_{12}$ receptors in shear-dependent thrombus formation on ruptured plaques. Plos One 2010;5:e10130.

36. Saelman EU, Kehrel B, Hese KM, de Groot PG, Sixma JJ, Nieuwenhuis HK. Platelet adhesion to collagen and endothelial cell matrix under flow conditions is not dependent on platelet glycoprotein IV. Blood 1994;83:3240-3244.

37. Nieswandt B, Watson SP. Platelet-collagen interaction: Is GPVI the central receptor? Blood 2003;102:449-461.

38. Auger JM, Kuijpers MJ, Senis YA, Watson SP, Heemskerk JW. Adhesion of human and mouse platelets to collagen under shear: A unifying model. FASEB J 2005;19:825-827.

39. Jackson SP, Mistry N, Yuan YP. Platelets and the injured vessel wall: Rolling into action. Focus on glycoprotein Ib/V/IX and the platelet cytoskeleton. Trends Cardiovasc Med 2000;10:192-197.

40. Kuijpers MJ, Schulte V, Oury C, Lindhout T, Broers J, Hoylaerts MF, Nieswandt B, Heemskerk JW. Facilitating roles of murine platelet glycoprotein $\mathrm{Ib}$ and aIIbb3 in phosphatidylserine exposure during vWF-collagen-induced thrombus formation. J Physiol 2004;558:403-415.

41. Jackson SP. The growing complexity of platelet aggregation. Blood 2007;109:5087-5095.

42. Heemskerk JW, Sakariassen KS, Zwaginga JJ, Brass LF, Jackson SP, Farndale RW, the Biorheology Subcommittee of the SSC, of the ISTH. Collagen surfaces to measure thrombus formation under flow: Possibilities for standardization. J Thromb Haemost 2011;9:856-858.

43. Sixma JJ, de Groot PG. Regulation of platelet adhesion to the vessel wall. Ann N Y Acad Sci 1994;714:190-199.

44. Ruggeri ZM. Platelet adhesion under flow. Microcirculation 2009;16:58-83.

45. Lisman T, Adelmeijer J, Cauwenberghs S, Van Pampus EC, Heemskerk JW, De Groot PG. Recombinant factor VIIa enhances platelet adhesion and activation under flow conditions at normal and reduced platelet count. J Thromb Haemost 2005;3:742-751. 
46. Okorie UM, Diamond SL. Matrix protein microarrays for spatially and compositionally controlled microspot thrombosis under laminar flow. Biophys J 2006;91:3474-3481.

47. Berny MA, Munnix IC, Auger JM, Schols SE, Cosemans JM, Panizzi P, Bock PE, Watson SP, McCarty OJ, Heemskerk JW. Spatial distribution of factor $\mathrm{Xa}$, thrombin, and fibrin(ogen) on thrombi at venous shear. PLoS One 2010;5:e10415.

48. Munnix IC, Kuijpers MJ, Auger J, Thomassen CM, Panizzi P, van Zandvoort MA, Rosing J, Bock PE, Watson SP, Heemskerk JW. Segregation of platelet aggregatory and procoagulant microdomains in thrombus formation: Regulation by transient integrin activation. Arterioscler Thromb Vasc Biol 2007;27:2484-2490.

49. Cosemans JM, Iserbyt BF, Deckmyn $\mathrm{H}$, Heemskerk JW. Multiple pathways to switch platelet integrins on and off. J Thromb Haemost 2008;6:1253-1261.

50. Heemskerk JW, Bevers EM, Lindhout T. Platelet activation and blood coagulation. Thromb Haemost 2002;88:186-193.

51. Brass LF. Thrombin and platelet activation. Chest 2003;124: 18S-25S.

52. Van der Meijden PE, Munnix IC, Auger JM, GoversRiemslag JW, Cosemans JM, Kuijpers MJ, Spronk HM, Watson SP, Renne T, Heemskerk JW. Dual role of collagen in factor XII-dependent thrombus formation. Blood 2009;114:881-890.

53. Munnix IC, Strehl A, Kuijpers MJ, Auger JM, van der Meijden PE, van Zandvoort MA, oude Egbrink MG, Nieswandt B, Heemskerk JW. The glycoprotein VI-phospholipase $\mathrm{Cg} 2$ signaling pathway controls thrombus formation induced by collagen and tissue factor in vitro and in vivo. Arterioscler Thromb Vasc Biol 2005;25:2673-2678.

54. Diamond SL. Tissue factor activity under flow. Thromb Res 2010;125:S29-S30.

55. Cosemans JM, Munnix IC, Wetzker R, Heller R, Jackson SP, Heemskerk JW. Continuous signaling via PI3K isoforms beta and gamma is required for platelet ADP receptor function in dynamic thrombus stabilization. Blood 2006;108:3045-3052.

56. Maxwell MJ, Westein E, Nesbitt WS, Giuliano S, Dopheide SM, Jackson SP. Identification of a 2-stage platelet aggregation process mediating shear-dependent thrombus formation. Blood 2007;109:566-576.

57. Meyer dos Santos S, Klinkhardt U, Schneppenheim R, Harder S. Using ImageJ for the quantitative analysis of flowbased adhesion assays in real-time under physiologic flow conditions. Platelets 2010;21:60-66.

58. Heemskerk JW, Willems GM, Rook MB, Sage SO. Ragged spiking of free calcium in ADP-stimulated human platelets: Regulation of puff-like calcium signals in vitro and ex vivo. J Physiol 2001;535:625-635.

59. Nesbitt WS, Giuliano S, Kulkarni S, Dopheide SM, Harper IS, Jackson SP. Intercellular calcium communication regulates platelet aggregation and thrombus growth. J Cell Biol 2003;160:1151-1161.

60. Gilio K, Munnix IC, Mangin P, Cosemans JM, Feijge MA, van der Meijden PE, Olieslagers S, ChrzanowskaWodnicka MB, Lillian R, Schoenwaelder S, et al. Nonredundant roles of phosphoinositide 3-kinase isoforms alpha and beta in glycoprotein VI-induced platelet signaling and thrombus formation. J Biol Chem 2009;284:33750-33762.

61. Siljander PR, Munnix IC, Smethurst PA, Deckmyn H, Lindhout T, Ouwehand WH, Farndale RW, Heemskerk JW. Platelet receptor interplay regulates collagen-induced thrombus formation in flowing human blood. Blood 2004;103: 1333-1341.

62. Nesbitt WS, Westein E, Tovar-Lopez FJ, Tolouei E, Mitchell A, Fu J, Carberry J, Fouras A, Jackson SP. A shear gradient-dependent platelet aggregation mechanism drives thrombus formation. Nat Med 2009;15:665-673.
63. Jones KL, Hughan SC, Dopheide SM, Farndale RW, Jackson SP, Jackson DE. Platelet endothelial cell adhesion molecule- 1 is a negative regulator of platelet-collagen interactions. Blood 2001;98:1456-1463.

64. Ono A, Westein E, Hsiao S, Nesbitt WS, Hamilton JR, Schoenwaelder SM, Jackson SP. Identification of a fibrinindependent platelet contractile mechanism regulating primary hemostasis and thrombus growth. Blood 2008;112: 90-99.

65. Auger JM, Watson SP. Dynamic tyrosine kinase-regulated signaling and actin polymerisation mediate aggregate stability under shear. Arterioscler Thromb Vasc Biol 2008;28: 1499-1504.

66. Goto S, Tamura N, Ishida H, Ruggeri ZM. Dependence of platelet thrombus stability on sustained glycoprotein IIb/IIIa activation through adenosine $5^{\prime}$-diphosphate receptor stimulation and cyclic calcium signaling. J Am Coll Cardiol 2006;47:155-162.

67. Cosemans JM, Van Kruchten R, Olieslagers S, Schurgers LJ, Verheyen FK, Munnix IC, Waltenberger J, AngelilloScherrer A, Hoylaerts MF, Carmeliet P, et al. Potentiating role of Gas6 and Tyro3, Axl and Mer (TAM) receptors in human and murine platelet activation and thrombus stabilization. J Thromb Haemost 2010;8:1797-1808.

68. Kuijpers MJ, Pozgajova M, Cosemans JM, Munnix IC, Eckes B, Nieswandt B, Heemskerk JW. Role of murine integrin $\mathrm{a} 2 \mathrm{~b} 1$ in thrombus stabilization and embolization: Contribution of thromboxane $\mathrm{A}_{2}$. Thromb Haemost 2007;98:1072-1080.

69. Cosemans JM, Schols SE, Stefanini L, de Witt S, Feijge MA, Hamulyak K, Deckmyn H, Bergmeier W, Heemskerk JW. Key role of glycoprotein $\mathrm{Ib} / \mathrm{V} / \mathrm{IX}$ and von Willebrand factor in platelet activation-dependent fibrin formation at low shear flow. Blood 2011;117:651-660.

70. Mizuno T, Sugimoto M, Matsui H, Hamada M, Shida Y, Yoshioka A. Visual evaluation of blood coagulation during mural thrombogenesis under high shear blood flow. Thromb Res 2008;121:855-864.

71. Van de Walle G, Schoolmeester A, Iserbyt BF, Cosemans JM, Heemskerk JW, Hoylaerts MF, Nurden A, Vanhoorelbeke K, Deckmyn H. Activation of aIIbb3 is sufficient but also an imperative prerequisite to activate $\mathrm{a} 2 \mathrm{~b} 1$ on platelets. Blood 2007;109:595-602.

72. Gilio K, Harper MT, Cosemans JM, Konopatskaya O, Munnix IC, Prinzen L, Leitges M, Liu Q, Molkentin JD, Heemskerk JW, et al. Functional divergence of platelet protein kinase $\mathrm{C}$ (PKC) isoforms in thrombus formation on collagen. J Biol Chem 2010;285:23410-23419.

73. Kulkarni S, Woollard KJ, Thomas S, Oxley D, Jackson SP. Conversion of platelets from a proaggregatory to a proinflammatory adhesive phenotype: Role of PAF in spatially regulating neutrophil adhesion and spreading. Blood 2007;110:1879-1886.

74. Hu H, Zhu L, Huang Z, Ji Q, Chatterjee M, Zhang W, Li N. Platelets enhance lymphocyte adhesion and infiltration into arterial thrombus. Thromb Haemost 2011;104:1184-1192.

75. Cattaneo M. Bleeding manifestations of congenital and druginduced defects of the platelet P2Y12 receptor for adenosine diphosphate. Thromb Haemost 2011;105(Suppl. 1):S67-S74.

76. Storey RF. Pharmacology and clinical trials of reversiblybinding P2Y12 inhibitors. Thromb Haemost 2011; 105(Suppl. 1):S75-S81.

77. Gurbel PA, Tantry US. Clopidogrel response variability and the advent of personalised antiplatelet therapy. A bench to bedside journey. Thromb Haemost 2011;106:265-271.

78. Siller-Matula JM, Krumphuber J, Jilma B. Pharmacokinetic, pharmacodynamic and clinical profile of novel antiplatelet 
drugs targeting vascular diseases. Br J Pharmacol 2010;159: 502-517.

79. Bossavy JP, Thalamas C, Sagnard L, Barret A, Sakariassen K, Boneu B, Cadroy Y. A double-blind randomized comparison of combined aspirin and ticlopidine therapy versus aspirin or ticlopidine alone on experimental arterial thrombogenesis in humans. Blood 1998;92:1518-1525.

80. Cadroy Y, Bossavy JP, Thalamas C, Sagnard L, Sakariassen K, Boneu B. Early potent antithrombotic effect with combined aspirin and a loading dose of clopidogrel on experimental arterial thrombogenesis in humans. Circulation 2000;101:2823-2828.

81. Mendolicchio GL, Zavalloni D, Bacci M, Corrada E, Marconi M, Lodigiani C, Presbitero P, Rota L, Ruggeri ZM. Variable effect of P2Y12 inhibition on platelet thrombus volume in flowing blood. J Thromb Haemost 2011;9:373-382.

82. Sakakibara M, Goto S, Eto K, Tamura N, Isshiki T, Handa S. Application of ex vivo flow chamber system for assessment of stent thrombosis. Arterioscler Thromb Vasc Biol 2002; 22:1360-1364
83. Andre $\mathrm{P}$, LaRocca $\mathrm{T}$, Delaney SM, Lin PH, Vincent $\mathrm{D}$, Sinha U, Conley PB, Phillips DR. Anticoagulants (thrombin inhibitors) and aspirin synergize with $\mathrm{P} 2 \mathrm{Y} 12$ receptor antagonism in thrombosis. Circulation 2003;108:2697-2703.

84. Favaloro EJ. Clinical utility of the PFA-100. Semin Thromb Hemost 2008;34:709-733.

85. Michelson AD. Methods for the measurement of platelet function. Am J Cardiol 2009;103:20A-26A.

86. Tsuji S, Sugimoto M, Miyata S, Kuwahara M, Kinoshita S, Yoshioka A. Real-time analysis of mural thrombus formation in various platelet aggregation disorders: Distinct sheardependent roles of platelet receptors and adhesive proteins under flow. Blood 1999;94:968-975.

87. Sugimoto $M$, Matsui $H$, Mizuno $T$, Tsuji S, Miyata $S$, Matsumoto M, Matsuda M, Fujimura Y, Yoshioka A. Mural thrombus generation in type $2 \mathrm{~A}$ and $2 \mathrm{~B}$ von Willebrand disease under flow conditions. Blood 2003;101:915-920.

88. Zwaginga JJ, Sakariassen KS, King MR, Diacovo TG, Grabowski EF, Nash G, Hoylaerts M, Heemskerk JW. Can blood flow assays help to identify clinically relevant differences in von Willebrand factor functionality in von Willebrand disease types 1-3? J Thromb Haemost 2007;5:2547-2549. 